\title{
Editorial: The New Zealand carbon cycle: from regional budget to global cycle
}

\author{
W. Troy Baisden · Martin R. Manning
}

Published online: 25 February 2011

(C) Springer Science+Business Media B.V. 2011

New Zealand-an isolated mid-latitude nation in the Southern Ocean-has provided unique viewpoints and information on the global $\mathrm{C}$ cycle for approximately 50 years. This special issue arises from a 2008 Royal Society of New Zealand workshop entitled, "Carbon: from Regional Budget to Global Cycle." Submissions published here highlight New Zealand's distinct contributions to global understanding.

Before briefly examining each contribution, many readers will appreciate a brief introduction to New Zealand's C cycle. Figure 1 displays the size and scope of New Zealand's C cycle, in comparison to the global $\mathrm{C}$ cycle. In this figure, the oceanic component has been estimated for the area of New Zealand's exclusive economic zone (EEZ), the 5th largest in the world. From this depiction, it becomes apparent that New Zealand's biospheric and ocean fluxes are comparatively large. The southern ocean surrounding New Zealand is globally significant because it is believed to be disproportionately important in the removal of anthropogenic $\mathrm{CO}_{2}$ from the atmosphere. On land, New Zealand has highly productive ecosystems that have capitalised on the potential for forest sinks under

W. T. Baisden ( $\square)$

National Isotope Centre, GNS Science, Lower Hutt,

New Zealand

e-mail: t.baisden@gns.cri.nz

\section{R. Manning}

Climate Change Research Institute, Victoria University, Wellington, New Zealand the Kyoto protocol (see Fig. 1) and provide a global reference point for soil $\mathrm{C}$ dynamics under stable pastoral land use. New Zealand's unique and isolated situation, combined with its small population of four million people, makes the high-quality long-term records presented here particularly valuable.

Among the most iconic records of the Earth's carbon cycle are time-series data of the concentration or isotopic composition of atmospheric $\mathrm{CO}_{2}$. In this special issue, we highlight a major update of the atmospheric $\Delta^{14} \mathrm{C}-\mathrm{CO}_{2}$ record for Wellington, New Zealand by Currie et al. (2010a). The data represents the world's longest continuous record of its type, beginning in late 1954. At that time-before accurate atmospheric $\mathrm{CO}_{2}$ concentration measurements began - the $\Delta^{14} \mathrm{C}-\mathrm{CO}_{2}$ values showed a clear depression below $0 \%$ due to the influence of fossil fuel burning. The record clearly demonstrates the release of ${ }^{14} \mathrm{C}$ from atmospheric testing of thermo-nuclear weapons before the 1963 nuclear test-ban treaty. Subsequently, the ongoing decline in $\Delta^{14} \mathrm{C}-\mathrm{CO}_{2}$ in this record-compared to similar records from the northern hemisphere-can play an important role in distinguishing the well-known release of ${ }^{14} \mathrm{C}$-free fossil fuel $\mathrm{CO}_{2}$ emissions from the larger but more uncertain $\mathrm{C}$ exchanges with long-lived biospheric and oceanic reservoirs (Randerson et al. 2002). It provides a critical baseline for other $\mathrm{C}$ cycle studies, such as those using $\Delta^{14} \mathrm{C}-\mathrm{CO}_{2}$ to infer rates of $\mathrm{C}$ turnover and transport in soil and other reservoirs (Baisden and Parfitt 2007; Baisden et al. 2010). 


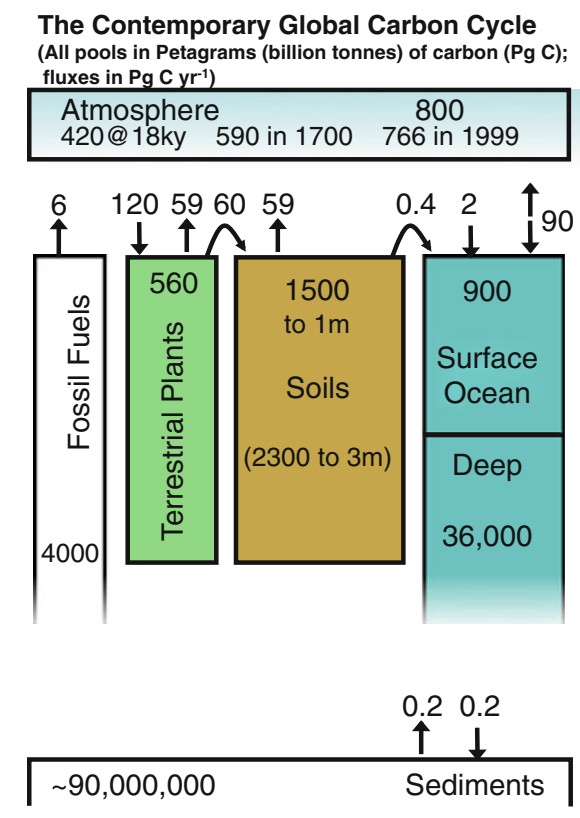

Fig. 1 A comparison of information on stocks and fluxes in the contemporary global and New Zealand C cycles, in $\sim 2007$. Information on the global $\mathrm{C}$ cycle is primarily compiled from the IPCC AR4 WG1 report (IPCC 2007), presented as an update to Sundquist (1993). Information on the New Zealand C budget has been generally compiled from Tate et al. (2005), Tate et al. (1997), and New Zealand's UNFCCC greenhouse gas inventory from 1990-2007. The estimated flux of riverine $C$ to the ocean is derived from Scott et al. (2006) and the combined net effect

Time-series records, such as the long-running Wellington $\Delta^{14} \mathrm{C}-\mathrm{CO}_{2}$ record, highlight the need for additional records to assist in tracking regional sources and sinks. One relatively new, and potentially valuable record is an 8 year bimonthly $\mathrm{pCO}_{2}$ record in a transect of the surface ocean extending from the east coast of the south island of New Zealand, eastsoutheasterly across a southern extension of the subtropical front and into subantarctic surface water (SASW). Currie et al. (2010b) record of $\mathrm{pCO}_{2}$ and supporting variables yields a strong net sink of atmospheric $\mathrm{CO}_{2}$ into SASW during most of the record, but not as strong a net sink as predicted by Takahashi et al. (2009). As the record continues, it will be intriguing to look for the expected increase in $\mathrm{pCO}_{2}$ and the correlation of net uptake with various phenomena, including climate oscillation indices.

Soil $\mathrm{C}$ is an even larger reservoir of $\mathrm{C}$ than the surface ocean and atmosphere, and is the subject of two studies in this issue. Schipper et al. (2010) investigate the difficult issue of understanding trends
The Contemporary New Zealand Carbon Cycle

(All pools in Teragrams (million tonnes) of carbon ( $\mathrm{Tg} \mathrm{C}$ );

fluxes in $\mathrm{Tg} \mathrm{C} \mathrm{yr}^{-1}$ )

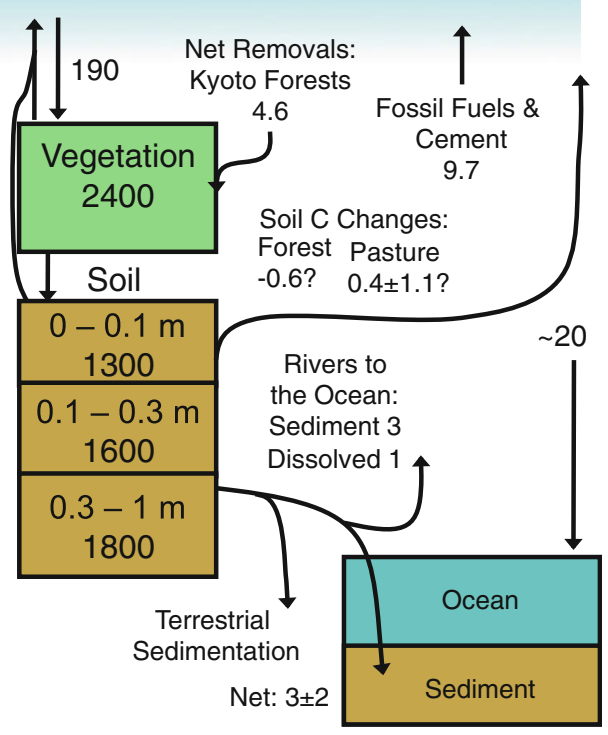

of terrestrial and marine sedimentation is estimated in Dymond (2010). We provide $\sim 20 \mathrm{Tg}$ of $\mathrm{C}$ uptake associated with the ocean around New Zealand as an initial estimate consistent with a $656 \mathrm{mmol} \mathrm{m}^{-2} \mathrm{y}^{-1}$ air-sea flux for 2001-2005 from Currie et al. (2010b) and approximately 3 million $\mathrm{km}^{2}$ of subantarctic surface water in New Zealand's exclusive economic zone. Comparison of Currie et al. (2010b) with much larger estimates from Takahashi et al. (2009) suggests large uncertainty in this term

in soil C stocks in pastoral soils in complex terrain. No relationship between $\mathrm{P}$ fertilisation levels was found, but soil C stocks demonstrated what appears to be significant variability over time. This variability is important to understand in properly monitoring soil $\mathrm{C}$ stocks, yet is not presently a common feature of most monitoring approaches. Thus, it is important to conclude that climate and other factors may meaningfully influence soil $\mathrm{C}$ stocks in grazing land irrespective of land management practices.

In a second study on historical soil C stocks, Schipper and Sparling (2010) mine a significant published 1964 dataset on soil C accumulation following land-use change from work that originally focussed on nutrient accumulation during conversions from woody vegetation to grazed grasslands over many decades. The authors find that initial mean rates of $\mathrm{C}$ accumulation of $1 \mathrm{MgC} \mathrm{ha}^{-1} \mathrm{y}^{-1}$ taper off to an apparent steady-state over time. The revisited dataset also highlights another key benefit of long-term studies-understanding the relationship 
between $\mathrm{C}$ and nutrients. In this case, understanding the rate at which $\mathrm{C}: \mathrm{N}$ declines to a stable value of approximately ten (reported on a mass basis) appears to define a point at which $N$ accumulation in soil effectively "saturates", increasing risk of $N$ losses from the agricultural system that degrade the environment (Schipper et al. 2004; Galloway et al. 2003).

A final contribution to this special issue (Enting 2010) reminds us that reinterpretation of long-term $C$ cycle records, and uniqueness of a nation's agriculture, forestry and emissions (including the mix of greenhouse gases) can meaningfully influence the interpretation of the metrics used to evaluate the climate dilemma at a political level. Enting presents his analysis in terms of the importance of " $\mathrm{C}$ consistency" in the interface between climate science and policy. He usefully demonstrates that different approaches can yield inconsistent information likely to raise serious concerns about our ability to reach an agreement to replace and extend the 1997 Kyoto protocol. Given the failure to reach a global treaty at Copenhagen (COP15) in 2009, and the selective steps taken at Cancun (COP16) in 2010, Enting's topic appears to have an underestimated relevance to the difficult task of getting developed and developing nations to agree on a consistent approach to stabilise the Earth's climate system.

New Zealand-a developed nation unusually dependent on the productivity of its land and ocean ecosystems - may play an important role in helping to establish consistency acceptable to both the developed and developing world. Enting's approach emphasises that historical scenarios of the activity of land and ocean sources and sinks, ultimately derived from long-term data (such as that presented in this special issue), play an important role in establishing the needed consistency, and therefore may be particularly valuable in New Zealand.

Acknowledgments We are grateful to Mike Harvey and the other organisers of the Royal Society of New Zealand Workshop that resulted in this special issue. Anonymous reviewers contributed helpful and timely reviews. We thank NZ FRST, GNS Science and Victoria University of Wellington for supporting our contribution as editors of this special issue.

\section{References}

Baisden W, Parfitt R (2007) Bomb ${ }^{14} \mathrm{C}$ enrichment indicates decadal $C$ pool in deep soil? Biogeochemistry 85(1):59-68
Baisden W, Parfitt RL, Ross C (2010) Radiocarbon evidence for contrasting soil carbon dynamics in a andisol and nonandisol pasture soil comparison. J Integr Field Sci 7: 59-64

Currie K, Brailsford G, Nichol S, Gomez A, Sparks R, Lassey $\mathrm{K}$, Riedel K (2010a) Tropospheric ${ }^{14} \mathrm{CO}_{2}$ at Wellington, New Zealand: the world's longest record. Biogeochemistry. doi:10.1007/s10533-009-9352-6

Currie K, Reid M, Hunter K (2010b) Interannual variability of carbon dioxide drawdown by subantarctic surface water near New Zealand. Biogeochemistry. doi:10.1007/s10533-0099355-3

Dymond JR (2010) Soil erosion in New Zealand is a net sink of $\mathrm{CO}_{2}$. Earth Surf Proc Land 35(15):1763-1772

Enting I (2010) Seeking carbon-consistency in the climate-science-to-policy interface. Biogeochemistry. doi:10.1007/ s10533-009-9351-7

Galloway JN, Aber JD, Erisman JW, Seitzinger SP, Howarth RW, Cowling EB, Cosby BJ (2003) The nitrogen cascade. Bioscience 53(4):341-356

IPCC (2007) Climate change 2007: the physical science basis. In: Solomon S, Qin D, Manning M, Chen Z, Marquis M, Averyt KB, Tignor M, Miller HL (eds) Contribution of working group I to the fourth assessment report of the intergovernmental panel on climate change. Cambridge University Press, Cambridge and New York

Randerson JT, Enting IG, Schuur EAG, Caldeira K, Fung IY (2002) Seasonal and latitudinal variability of troposphere $\Delta^{14} \mathrm{CO}_{2}$ : post bomb contributions from fossil fuels, oceans, the stratosphere, and the terrestrial biosphere. Global Biogeochem Cycles 16(4):1112. doi:1110.1029/ 2002GB001876

Schipper L, Sparling G (2010) Accumulation of soil organic C and change in $\mathrm{C}: \mathrm{N}$ ratio after establishment of pastures on reverted scrubland in New Zealand. Biogeochemistry. doi: 10.1007/s10533-009-9367-z

Schipper LA, Percival HJ, Sparling GP (2004) An approach for estimating when soils will reach maximum nitrogen storage. Soil Use Manag 20(3):281-286

Schipper L, Dodd M, Fisk L, Power I, Parenzee J, Arnold G (2010) Trends in soil carbon and nutrients of hill-country pastures receiving different phosphorus fertilizer loadings for 20 years. Biogeochemistry. doi:10.1007/s10533-0099353-5

Scott DT, Baisden WT, Davies-Colley R, Gomez B, Hicks DM, Page MJ, Preston NJ, Tate KR, Trustrum NA, Woods RA (2006) Localized erosion affects New Zealand's national C budget. Geophys Res Lett 33:L01402. doi:10.1029/2005 GL024644

Sundquist ET (1993) The global carbon dioxide budget. Science 259(5097):934-941

Takahashi T, Sutherland SC, Wanninkhof R, Sweeney C, Feely RA, Chipman DW, Hales B, Friederich G, Chavez F, Sabine C, Watson AJ, Bakker DCE, Schuster U, Metzl N, Yoshikawa-Inoue H, Ishii M, Midorikawa T, Nojiri Y, Kortzinger A, Steinhoff T, Hoppema M, Olafsson J, Arnarson TS, Tilbrook B, Johannessen T, Olsen A, Bellerby R, Wong CS, Delille B, Bates NR, De Baar HJW (2009) Climatological mean and decadal change in surface ocean $\mathrm{pCO}_{2}$, and net sea-air $\mathrm{CO}_{2}$ flux over the global 
oceans. Deep-Sea Res II 56:554-557. doi:10.1016/j.dsr2. 2008.12.009

Tate KR, Giltrap DJ, Claydon JJ, Newsome PF, Atkinson IAE, Taylor MD, Lee R (1997) Organic carbon stocks in New Zealand's terrestrial ecosystems. J Royal Soc N Z 27(3): 315-335
Tate KR, Wilde RH, Giltrap DJ, Baisden WT, Saggar S, Trustrum NA, Scott NA, Barton JR (2005) Soil organic carbon stocks and flows in New Zealand: system development, measurement and modelling. Can J Soil Sci 85(4):481-489 